\title{
Correction to: Fertility Intentions Within a 3-Year Time Frame: a Comparison Between Migrant and Native Italian Women
}

\author{
Eleonora Mussino ${ }^{1}$ (D) $\cdot$ Giuseppe Gabrielli $^{2}$ (D) Livia Elisa Ortensi ${ }^{3}$. \\ Salvatore Strozza ${ }^{2}$
}

Published online: 16 July 2021

(C) The Author(s) 2021

\section{Correction to: Journal of International Migration and Integration https://doi.org/10.1007/s12134-020-00800-2}

The article "Fertility Intentions Within a 3-Year Time Frame: a Comparison Between Migrant and Native Italian Women," written by Eleonora Mussino, Giuseppe Gabrielli, Livia Elisa Ortensi and Salvatore Strozza, was originally published electronically on the publisher's Internet portal on 4 January 2021 without open access. With the author(s)' decision to opt for Open Choice the copyright of the article changed on June 2021 to (C) The Author(s) 2021, the article is forthwith distributed under a Creative Commons Attribution 4.0 International License, which permits use, sharing, adaptation, distribution and reproduction in any medium or format, as long as you give appropriate credit to the original author(s) and the source, provide a link to the Creative Commons licence and indicate if changes were made. The images or other third party materials in this article are included in the article's Creative Commons licence, unless indicated otherwise in a credit line to the material. If material is not included in the article's Creative Commons licence and your intended use is not permitted by statutory regulation or exceeds the permitted use, you will need to obtain permission directly

The online version of the original article can be found at https://doi.org/10.1007/s12134-020-00800-2

Eleonora Mussino

eleonora.mussino@sociology.su.se

$\triangle$ Giuseppe Gabrielli

giuseppe.gabrielli@unina.it

1 Stockholm University, Stockholm, Sweden

2 University of Naples Federico II, Naples, Italy

3 Alma Mater Studiorum University of Bologna, Bologna, Italy 
from the copyright holder. To view a copy of this licence, visit http://creativecommons. org/licenses/by/4.0.

The original article has been corrected.

Open Access This article is licensed under a Creative Commons Attribution 4.0 International License, which permits use, sharing, adaptation, distribution and reproduction in any medium or format, as long as you give appropriate credit to the original author(s) and the source, provide a link to the Creative Commons licence, and indicate if changes were made. The images or other third party material in this article are included in the article's Creative Commons licence, unless indicated otherwise in a credit line to the material. If material is not included in the article's Creative Commons licence and your intended use is not permitted by statutory regulation or exceeds the permitted use, you will need to obtain permission directly from the copyright holder. To view a copy of this licence, visit http://creativecommons.org/licenses/by/4.0/.

Publisher's Note Springer Nature remains neutral with regard to jurisdictional claims in published maps and institutional affiliations. 